\title{
Conservation efficiency and nutritive value of silages made from grass-red clover and multi-species swards compared with grass monocultures
}

\author{
T. Moloney ${ }^{1,2}$, H. Sheridan ${ }^{2}$, J. Grant ${ }^{3}$, E.G. O'Riordan ${ }^{1}$, P. O’Kiely ${ }^{1 \dagger}$
}

${ }^{1}$ Teagasc, Animal \& Grassland Research and Innovation Centre, Grange, Dunsany, Co. Meath, Ireland

${ }^{2}$ School of Agriculture and Food Science, University College Dublin, Dublin 4, Ireland

${ }^{3}$ Teagasc, Food Research Centre, Ashtown, Dublin 15, Ireland

Abstract

Binary grass-clover and multi-species swards can increase herbage yields or facilitate reduced inputs of inorganic fertiliser nitrogen $(N)$ compared with perennial ryegrass monocultures. However, the efficiency of the ensilage process and the nutritive value of silage produced from multi-species swards has not been documented. Replicate samples from grass-red clover binary mixture and multi-species mixture swards were ensiled in laboratory silos to assess the ensilability, fermentation characteristics, conservation losses and silage nutritive value compared with grass monocultures produced using inorganic $\mathbf{N}$ fertiliser. The results suggest that assessment of the ensilability and subsequent ensilage characteristics of binary and multi-species mixtures should be based on direct sampling from such mixtures rather than being predicted from values obtained from monocultures of constituent species. Under favourable ensiling conditions, unwilted binary mixtures and multi-species mixtures are satisfactorily preserved as silage, comparable to a perennial ryegrass monoculture receiving inorganic $\mathrm{N}$ fertiliser. However, when ensiled under more challenging crop conditions the mixtures exhibited a greater requirement for their preservation to be aided, compared with the perennial ryegrass monoculture. Despite the application of inorganic $\mathbf{N}$ reducing the legume content of multi-species mixture swards, it had relatively little effect on herbage ensilability or silage preservation. For all species treatments, silage nutritive values were primarily dependent on the pre-ensiling values, although herbage digestibility values declined during ensilage where the ensilage process was inefficient. The current study suggests that in order to be satisfactorily preserved as silage, binary grass-clover and multispecies swards have a greater requirement for an adequate rapid field wilt and/or effective preservative application compared with perennial ryegrass produced using inorganic fertiliser $\mathbf{N}$.

Keywords

Conservation losses $\cdot$ ensilability $\cdot$ fermentation $\bullet$ nutritive value $\bullet$ silage

\section{Introduction}

In temperate grass-based ruminant production systems such as those in Ireland, grass silage is the primary forage available for livestock during the winter period when weather conditions can make grazing unfeasible. Ideally, for satisfactory preservation as silage, a crop should have an adequate supply of fermentable substrate in the form of water-soluble carbohydrates (WSC) and a relatively low buffering capacity. When WSC is expressed on an aqueous phase basis $\left(\mathrm{WSC}_{\mathrm{aq}}\right)$, then increasing herbage DM content, by means of field wilting, for example, also improves ensilability (Buxton \& O’Kiely, 2003).

Perennial ryegrass (Lolium perenne L.) is the most commonly sown grass species in temperate regions due to its versatility in both conservation and/or grazing management regimes, exhibiting good yield and silage preservation potential as well as high digestibility and persistence (Frame \& Laidlaw, 2011). However, other grass species such as Italian ryegrass (Lolium multiflorum L.) are better suited to silage production due to a greater WSC content (Burns et al., 2015), while timothy (Phleum pratense L.) is preferred in colder regions due to its cold hardy nature (Bélanger et al., 2001).

The satisfactory preservation of legume species such as red (Trifolium pratense L.) and white (Trifolium repens L.) clover can be difficult due to their characteristically low WSC and high buffering capacity (Buxton \& O'Kiely, 2003). However, despite their apparently poor ensilability characteristics, legume monocultures and grass-legume binary swards can undergo satisfactory lactic acid-dominant fermentation (Dewhurst et al., 2003; King et al., 2012a; Copani et al., 2014). Red clover is used mainly in swards managed to produce conserved fodder 
and is typically grown with a companion grass species such as perennial ryegrass. The primary function of the companion grass is to increase herbage DM yield, but it can also improve the overall ensilability (Clavin et al., 2017). White clover has an important role in grassland swards for grazing (Phelan et al., 2015), and its shallow rooting nature has made it a particularly successful partner for perennial ryegrass (Black et al., 2009). Alternative forage herbs such as chicory (Cichorium intybus L.) and ribwort plantain (Plantago lanceolata L.) can contribute to improved herbage yields and nutritive value (Sanderson et al., 2003; Deak et al., 2007; Pirhofer-Walzl et al., 2011), but little research has been reported on the preservation of these species as silage either in monoculture or in mixtures with grasses and/or legumes. However, the relatively high WSC content reported for chicory by Barry (1998), for example, is encouraging.

Sown multi-species grassland swards can transgressively overyield due to temporal and spatial complementarity among the sown species and also to interspecific facilitation such as the transfer of symbiotically fixed $\mathrm{N}$ from legumes to neighbouring species (Nyfeler et al., 2009; Finn et al., 2013; Lüscher et al., 2014). Although sward botanical composition can influence herbage chemical composition (Sanderson, 2010) the nutritive value of multi-species swards can differ from what would be expected based on the chemical composition of the component species grown in monoculture (Moloney et al. 2020a; Ergon et al., 2017). This, in turn, raises the possibility that indices of ensilability and ultimately conservation efficiency may also differ from what might be predicted from values obtained for the constituent species grown in monoculture.

The current paper follows two earlier studies which examined the yield and botanical composition (Moloney et al., 2020b) and the nutritive value (Moloney et al. 2020a) of binary and multi-species mixtures compared with a number of temperate grassland species monocultures managed under a fourcut annual silage production regime where the response of multi-species mixtures to inorganic nitrogen $(\mathrm{N})$ was also determined.

The objectives of the current study were to quantify the effects on herbage ensilability and silage nutritive value, fermentation characteristics and conservation losses of (1) three common temperate grass monocultures receiving inorganic $\mathrm{N}$ or grown in binary mixture with red clover, and a red clover monoculture, (2) a perennial ryegrass monoculture receiving $360 \mathrm{~kg} \mathrm{~N} / \mathrm{ha}$ per year compared with a perennial ryegrass/red clover binary mixture and two multi-species mixtures, each receiving no inorganic $\mathrm{N}$ fertiliser, (3) a perennial ryegrass monoculture and two multi-species mixtures each receiving $360 \mathrm{~kg} \mathrm{~N} / \mathrm{ha}$ per year, and (4) two multi-species mixtures receiving either 0 or $360 \mathrm{~kg} \mathrm{~N} /$ ha per year. Herbage was ensiled without the assistance of either wilting or the application of additives so as to best assess the inherent ensilability of the various sward treatments.

\section{Materials and methods}

\section{Field plots}

Field plots (each $9 \mathrm{~m} \times 2 \mathrm{~m}$ ) were established at Teagasc Grange $\left(53.52^{\circ} \mathrm{N}, 6.66^{\circ} \mathrm{W}\right)$, and details of soil characteristics, treatment establishment and general plot management have been described by Moloney et al. (2020b). The herbages used in this study were obtained from Year 1 of the (Moloney et al., 2020 b) study which corresponds to the second year after sowing. Eleven treatments (Table 1) from each of four replicate blocks

Table 1: Sward types and the associated species included, rates of seed used, and rates of inorganic $\mathrm{N}$ applied

\begin{tabular}{|c|c|c|c|}
\hline Sward & Species included ${ }^{1}$ & Seed rate ${ }^{2}$ & $\mathbf{N}^{3}$ \\
\hline TIM/360N & Timothy & 15 & 360 \\
\hline IRG/360N & Italian ryegrass & 42 & 360 \\
\hline PRG/0-360N & Perennial ryegrass & 32 & 0,360 \\
\hline $\mathrm{RC}$ & Red clover & 15 & 0 \\
\hline $\mathrm{TIM} / \mathrm{RC}$ & Timothy, red clover & 6,9 & 0 \\
\hline IRG/RC & Italian ryegrass, red clover & $16.8,9$ & 0 \\
\hline PRG /RC & Perennial ryegrass, red clover & $12.8,9$ & 0 \\
\hline Mix 1/0-360 & Timothy, perennial ryegrass, red clover, white clover & $3,6.4,5.25,3$ & 0,360 \\
\hline Mix 2/0-360 & Timothy, perennial ryegrass, red clover, ribwort plantain, chicory & $3,6.4,5.25,1.5,0.63$ & 0,360 \\
\hline
\end{tabular}

${ }^{1}$ Perennial ryegrass in binary- or multi-species mixtures was always intermediate heading-date, diploid cultivars (as per PRG).

${ }^{2} \mathrm{~kg}$ seed/ha (values correspond in order with species in the preceding column).

${ }^{3}$ Inorganic fertiliser $\mathrm{N}$ input (kg N/ha per year). 
were used in this experiment and constituted a randomised complete block design. A single representative sample of harvested herbage was collected from each treatment plot and thus both the experimental unit and replication were at the field plot level. Five monoculture or multi-species mixtures were grown using $360 \mathrm{~kg}$ of inorganic fertiliser $\mathrm{N} / \mathrm{ha}$ per year, and these were Italian ryegrass (IRG/360N), perennial ryegrass (PRG/360N), timothy (TIM/360N), Mix 1 (perennial ryegrass, timothy, red and white clovers; Mix 1/360N) and Mix 2 (perennial ryegrass, timothy, red clover, ribwort plantain and chicory; Mix 2/360N). A further five treatments comprised binary or multi-species mixtures grown without inorganic fertiliser $\mathrm{N}$ input. These were binary mixtures of Italian ryegrass (IRG/RC), perennial ryegrass (PRG/RC) and timothy (TIM/ $\mathrm{RC}$ ) with red clover, as well as Mix $1 / 0 \mathrm{~N}$ and Mix $2 / 0 \mathrm{~N}$. The final treatment was a red clover monoculture grown without inorganic $\mathrm{N}$ input (RC). The species included in each herbage treatment were represented by an equal proportion of three cultivars (two for chicory and one for ribwort plantain). Details of the cultivars used and their seeding rates are presented in Tables 1 and 2. The annual production from each plot was harvested in four cuts (Cuts 1-4) taken on 27 May, 15 July, 2 September and 10 November, with the herbage harvested at Cuts 1-3 being used in this experiment. The inorganic $\mathrm{N}$ (calcium ammonium nitrate; $275 \mathrm{~g} \mathrm{~N} / \mathrm{kg}$ ) was applied at 120 , 100,80 and $60 \mathrm{~kg} \mathrm{~N} / \mathrm{ha}$ in mid-March and immediately after Cuts 1-3, respectively. Individual samples of each species growing in Mix 1 and Mix 2 and receiving $120 \mathrm{~kg} \mathrm{~N} /$ ha per year were also taken and their chemical composition determined.

At each cut, the herbage was harvested to a 6-cm stubble height using a Haldrup forage plot harvester (J. Haldrup, Løgstør, Denmark) before being passed through a precision-chop forage harvester (MEX V1, Pottinger, Grieskirchen, Austria) set to a theoretical chop length of $19 \mathrm{~mm}$. A representative $6 \mathrm{~kg}$ sample from each plot was immediately ensiled in a laboratory silo (O'Kiely \& Wilson, 1991) for 100 days at approximately $15^{\circ} \mathrm{C}$. The sealed silos accommodated steel weights to apply practical levels of pressure to the compacted herbage and permitted the drainage of effluent throughout the ensilage and its separate storage beneath the silage. At the silo opening, the silage and effluent were weighed and sampled. Silage DM recovery was calculated as the weight of silage DM removed from the silo expressed as a proportion of the weight of herbage DM ensiled. Samples of herbage taken pre- and post-ensilage were stored at $-18^{\circ} \mathrm{C}$ prior to chemical analysis. Sward botanical composition was determined on pre-ensilage samples and was reported by (Moloney et al., 2020b).

\section{Chemical analysis}

Representative samples of pre-ensilage herbage were dried at $98^{\circ} \mathrm{C}$ for $16 \mathrm{~h}$ in an oven with forced air circulation, while post-ensilage samples were dried at $40^{\circ} \mathrm{C}$ for $48 \mathrm{~h}$ to estimate silage DM content. Sub-samples of the pre- and post-ensilage herbage were dried at $60^{\circ} \mathrm{C}$ and $40^{\circ} \mathrm{C}$ for $48 \mathrm{~h}$, respectively, before being milled through a $1 \mathrm{~mm}$ aperture sieve (Wiley mill, $1 \mathrm{~mm}$ pore screen). In vitro DM digestibility (DMD) was then determined using the method of Tilley and Terry (1963) with the modification that the final residue was isolated by filtration (Whatman GF/A $55 \mathrm{~mm}$, pore size $1.6 \mu \mathrm{m}$; Whatman International, Maidstone, UK) rather than by centrifugation. WSC content was measured using the anthrone method on an Autoanalyser 3 (Bran and Leubbe $\mathrm{GmbH}$, Norderstedt, Germany) and, for pre-ensilage herbage only, expressed on an aqueous phase (WSC ${ }_{\text {aq }}$ g/kg aqueous extract) basis, while ash was determined by complete combustion in a muffle furnace at $550^{\circ} \mathrm{C}$ for $5 \mathrm{~h}$. The crude protein (CP) content ( $\mathrm{N}$ $\times 6.25$ ) was determined using a LECO FP $428 \mathrm{~N}$ analyser (Leco Instruments, St. Joseph, MI, USA) based on the method 990-03 of the Association of Analytical Chemists (AOAC) (1990). Herbage buffering capacity was determined for preensilage herbage only according to the method of Playne and

Table 2: Species and cultivars used

\begin{tabular}{lc}
\hline Species & Cultivar $^{1}$ \\
\hline Timothy (Phleum pratense L.) (TIM) & Comer (9/6; H), Erecta (10/6; H), Promesse (10/6; H) \\
Italian ryegrass (Lolium multiflorum Lam.) (IRG) & Fabio (19/5; T), Nabucco (21/5; T), Davinci (23/5; D) \\
Perennial ryegrass (Lolium perenne L.) (PRG) & Premium (23/5; D), Shandon (21/5; D), Solomon (22/5; D) \\
Red clover (Trifolium pratense L.) (RC) & Aberruby (D), Amos (T), Merviot (D) (all early flowering) \\
White clover (Trifolium repens L.) & Aran (very large leaf), Barblanca (large leaf), Chieftain (medium leaf) \\
Ribwort plantain (Plantago lanceolata L.) & Ceres Tonic (D) \\
Chicory (Cichorium intybus L.) & Grasslands Choice (D), Puna (D) \\
\hline
\end{tabular}

${ }^{1}$ Heading date (date/month), ploidy ( $\mathrm{D}$ - diploid, $\mathrm{T}$ - tetraploid, $\mathrm{H}$ - hexaploid) and other cultivar classification characteristics. PRG cultivars were all of intermediate heading date. 
McDonald (1966) using an 809 Titrando Universal Titrator and Titrosampler (Metrohm, Herisau, Switzerland). Pre-ensilage DMD, CP, WSC and ash have been reported by Moloney et al. (2020a).

Aqueous extracts were obtained from each silage sample, and $\mathrm{pH}$ was determined using a $\mathrm{pH}$ electrode (HI98127; Hanna Instruments Ltd., Leighton Buzzard, Bedfordshire, UK). L-lactic acid concentration was determined using the SP-Ace Clinical Chemical Analyzer, (Alfa Wassermann Inc., West Caldwell, NJ, USA) and the L-lactic acid ultraviolet (UV)-method test kit (catalogue no. 101309084035; Roche/ R-Biopharm, Darmstadt, Germany), whereas D-lactate concentration was determined using the enzyme D-lactate dehydrogenase (catalogue no. 1016941001; Roche/RBiopharm). The concentration of ammonia $\left(\mathrm{NH}_{3}\right)$ was determined using the SP-Ace Clinical Chemical Analyzer and the Thermo Electron Infinity ammonia liquid stable reagent kinetic method (Thermo Fisher Scientific Inc., Waltham, MA, USA).

A fermentation coefficient for pre-ensiled herbage was calculated according to Weissbach and Honig (1996) as follows:

$$
\mathrm{DM}+\frac{8 \times \mathrm{WSC}_{\mathrm{dm}}}{\mathrm{BC}}
$$

where $\mathrm{DM}=\mathrm{DM} \mathrm{g} / 100 \mathrm{~g} ; \mathrm{WSC}_{\mathrm{dm}}=\mathrm{WSC}$ of pre-ensiled herbage on a DM basis; $\mathrm{BC}=$ buffering capacity expressed as $\mathrm{g}$ lactic acid $/ \mathrm{kg} \mathrm{DM}$, calculated as 0.1545 buffering capacity (mEq/kg DM) - 2.1153.

The index of Flieg's point (Moselhy et al., 2015) was used as a gauge of the general standard of silage preservation and was calculated as follows:

$$
220+((2 \times \mathrm{DM})-15)-(40 \times \mathrm{pH})
$$

where DM was expressed as $\mathrm{g} / 100 \mathrm{~g}$. According to this index, silage preservation was considered "very bad" at values $<20$, "bad" between 21 and 40, "medium" between 41 and 60, "good" between 61 and 80, and "very good" between 81 and 100.

\section{Statistical analysis}

The analysis was fitted as a one-way classification of 11 treatments which accounted for the four replicate blocks, using the Mixed procedure in SAS 9.4 (SAS, 2013). Within the 11 treatments, there were two subsets with a factorial structure and two subsets with simple contrasts. These constituted four groupings of treatment that addressed the four objectives of the study described previously. Group 1 included seven treatments (PRG/360N, IRG/360N, TIM/360N, PRG/RC, IRG/ $R C, T I M / R C$ and $R C)$ to give a $(3 \times 2)+1$ arrangement with the +1 (i.e. RC) being a control. Group 2 and Group 3 were simple four- (PRG/360N, PRG/RC, Mix 1/0N and Mix 2/0N) and three- (PRG/360N, Mix 1/360N and Mix 2/360N) level oneway classifications, while Group 4 included four treatments (Mix 1/0N, Mix 1/360N, Mix 2/0N and Mix 2/360N) organised in a $2 \times 2$ factorial arrangement. In order to accommodate these structures, a series of contrasts were used to evaluate interactions and associated main effects. Main effect means were estimated and compared where appropriate for each of the three cuts separately. Residual checks were made to ensure that the assumptions of the analysis were met. Depending on the results of the interaction tests, multiple comparison adjustments were made (step-down Bonferroni adjustment), for each variable analysed, for each of the relevant sets of comparisons.

\section{Results}

Perennial ryegrass, Italian ryegrass and timothy receiving inorganic N or grown with red clover (Group 1; PRG/360N, IRG/360N, TIM/360N, PRG/RC, IRG/RC, TIM/RC and RC)

\section{Herbage ensilability}

At Cut 1 (Tables 3 and 4 ), herbage $\mathrm{WSC}_{\mathrm{aq}}$ content was greater $(P<0.05)$ for Italian ryegrass-based treatments (IRG/360N plus IRG/RC) than for perennial ryegrass-based treatments (PRG/360N plus PRG/RC) which were in turn greater $(P<0.05)$ than timothy-based treatments $(\mathrm{TIM} / 360 \mathrm{~N}$ plus TIM/RC) and RC. Furthermore, at both Cuts 1 and 2, IRG/RC and IRG/360N had greater $(P<0.01) \mathrm{WSC}_{\mathrm{aq}}$ than RC while at Cut 2 (Tables 5 and 6), Italian ryegrass-based treatments had greater $(P<0.01)$ WSC $_{\text {aq }}$ content than both perennial ryegrass- and timothy-based treatments, with the magnitude of difference being greater when each grass was grown with red clover than inorganic N. At Cut 3 (Tables 7 and 8$), I R G / 360 N$ and $P R G / 360 N$ had a greater $(P<0.01)$ WSC $_{\text {aq }}$ content than TIM/360N, while IRG/RC had a greater WSC $_{\mathrm{aq}}$ than both PRG/RC and TIM/RC with RC being intermediate.

Herbage buffering capacity at Cut 1 was greater $(P<0.05)$ for timothy-based treatments than for Italian ryegrass-based treatments, with perennial ryegrass-based treatments being intermediate, while RC had a greater $(P<0.01)$ buffering capacity than all other treatments. At Cut 2 , the buffering capacity was greater $(P<0.01)$ for RC, PRG/RC and TIM/RC than for IRG/RC, while there was no difference $(P>0.05)$ in the buffering capacity of IRG/360N, PRG/360N or TIM/360N. At Cut 3 , the buffering capacity was greatest $(P<0.01)$ for $\mathrm{RC}$, while perennial ryegrass-based treatments had greater $(P<0.01)$ buffering capacity than timothy-based treatments which were greater $(P<0.01)$ than Italian ryegrass-based treatments. Furthermore, values were greater $(P<0.001)$ 


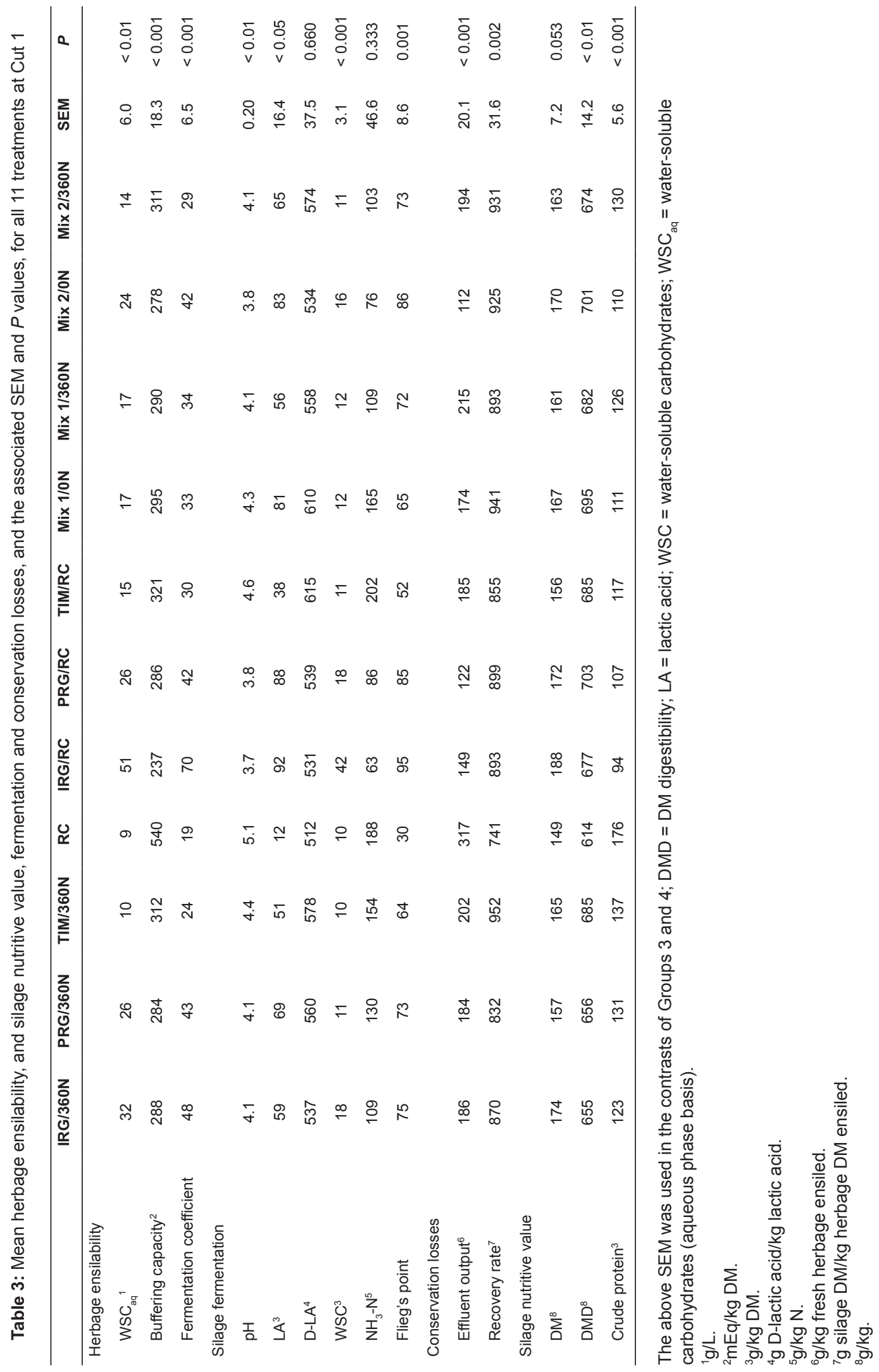


Table 4: SEM and $P$ values for herbage ensilability, and silage nutritive value, fermentation and conservation losses for the main effects and interactions for two groups of treatments at Cut 1

\begin{tabular}{|c|c|c|c|c|c|c|c|c|c|c|c|c|}
\hline \multirow[t]{5}{*}{ Group 1} & \multicolumn{6}{|l|}{1} & \multicolumn{6}{|l|}{4} \\
\hline & \multicolumn{2}{|l|}{ Species $^{2}$} & \multicolumn{2}{|l|}{$\mathrm{N}$ source $^{3}$} & \multicolumn{2}{|l|}{ Species } & \multicolumn{2}{|l|}{$\operatorname{Mix}^{4}$} & \multicolumn{2}{|l|}{$\mathrm{N}$ rate $^{5}$} & \multicolumn{2}{|l|}{ Mix } \\
\hline & \multicolumn{10}{|c|}{$\mathbf{x}$} & \multicolumn{2}{|l|}{$x$} \\
\hline & \multicolumn{9}{|c|}{$\mathrm{N}$ source } & \multicolumn{3}{|c|}{$\mathrm{N}$ rate } \\
\hline & SEM & $P$ & SEM & $P$ & SEM $^{6}$ & $P$ & SEM & $P$ & SEM & $P$ & SEM & $P$ \\
\hline \multicolumn{13}{|l|}{ Herbage ensilability } \\
\hline $\mathrm{WSC}_{\mathrm{aq}}{ }^{7}$ & 4.2 & $<0.001$ & 3.5 & 0.105 & 6 & 0.289 & 4.2 & 0.741 & 4.2 & 0.411 & 6 & 0.384 \\
\hline Buffering capacity ${ }^{8}$ & 13 & 0.021 & 10.6 & 0.366 & 18.3 & 0.221 & 13 & 0.899 & 13 & 0.452 & 18.3 & 0.307 \\
\hline Fermentation coefficient & 4.6 & $<0.001$ & 3.7 & 0.09 & 6.5 & 0.181 & 4.6 & 0.765 & 4.6 & 0.344 & 0.329 & 6.5 \\
\hline \multicolumn{13}{|l|}{ Silage fermentation } \\
\hline $\mathrm{pH}$ & 0.14 & 0.013 & 0.11 & 0.427 & 0.2 & 0.225 & 0.14 & 0.188 & 0.14 & 0.793 & 0.2 & 0.227 \\
\hline $\mathrm{LA}^{9}$ & 10.8 & 0.064 & 9 & 0.291 & 16.4 & 0.313 & 10.8 & 0.691 & 10.8 & 0.156 & 16.4 & 0.795 \\
\hline D-LA ${ }^{10}$ & 26.5 & 0.238 & 21.7 & 0.925 & 37.5 & 0.729 & 26.5 & 0.441 & 26.5 & 0.871 & 37.5 & 0.228 \\
\hline WSC $^{9}$ & 2.2 & $<0.001$ & 1.8 & $<0.001$ & 3.1 & 0.002 & 2.2 & 0.506 & 2.2 & 0.419 & 3.1 & 0.472 \\
\hline $\mathrm{NH} 3-\mathrm{N}^{11}$ & 30.6 & 0.105 & 25.6 & 0.692 & 46.6 & 0.476 & 30.6 & 0.239 & 30.6 & 0.712 & 46.6 & 0.309 \\
\hline Flieg's point & 6.1 & 0.009 & 4.9 & 0.357 & 8.6 & 0.169 & 6.1 & 0.205 & 6.1 & 0.696 & 8.6 & 0.254 \\
\hline \multicolumn{13}{|l|}{ Conservation losses } \\
\hline Effluent output ${ }^{12}$ & 15.5 & 0.166 & 12.3 & 0.03 & 20.1 & 0.556 & 15.5 & 0.059 & 15.5 & 0.006 & 20.1 & 0.324 \\
\hline Recovery rate ${ }^{13}$ & 22.3 & 0.491 & 18.2 & 0.925 & 31.6 & 0.038 & 22.3 & 0.734 & 22.3 & 0.51 & 31.6 & 0.389 \\
\hline \multicolumn{13}{|l|}{ Silage nutritive value } \\
\hline $\mathrm{DM}^{14}$ & 5.1 & 0.016 & 4.2 & 0.265 & 7.2 & 0.191 & 5.1 & 0.756 & 5.1 & 0.376 & 7.2 & 0.894 \\
\hline $\mathrm{DMD}^{14}$ & 10 & 0.613 & 8.2 & 0.016 & 14.2 & 0.536 & 10 & 0.937 & 10 & 0.171 & 14.2 & 0.643 \\
\hline Crude protein ${ }^{9}$ & 4 & 0.009 & 3.3 & $<0.001$ & 5.6 & 0.778 & 4 & 0.792 & 4 & 0.004 & 5.6 & 0.66 \\
\hline
\end{tabular}

DMD = DM digestibility; IRG = Italian ryegrass; $L A=$ lactic acid; PRG = perennial ryegrass; $R C=$ red clover; TIM = timothy; WSC = watersoluble carbohydrates; WSC $_{\mathrm{aq}}=$ water-soluble carbohydrates (aqueous phase basis).

${ }^{1}$ Group $1=$ IRG/360N, PRG/360N, TIM/360N, IRG/RC, PRG/RC, TIM/RC with RC as a control; Group $4=$ Mix 1/0N, Mix 1/360N, Mix 2/0N and Mix $2 / 360 N$.

${ }^{2}$ Species $=$ PRG, IRG and TIM.

${ }^{3} \mathrm{~N}$ source $=360 \mathrm{~kg} \mathrm{~N} /$ ha per year or RC.

${ }^{4} \mathrm{Mix}=\operatorname{Mix} 1$ or $\operatorname{Mix} 2$.

${ }^{5} \mathrm{~N}$ rate $=0$ or $360 \mathrm{~kg} \mathrm{~N} / \mathrm{ha} /$ year.

${ }^{6}$ This SEM was calculated for the $3 \times 2$ interaction but is also used when comparing RC to any of the $3 \times 2$ treatments.

${ }^{7} \mathrm{~g} / \mathrm{L}$.

${ }^{8} \mathrm{mEq} / \mathrm{kg} \mathrm{DM}$

${ }^{9} \mathrm{~g} / \mathrm{kg} \mathrm{DM}$.

${ }^{10} \mathrm{~g}$ D-lactic acid.

${ }^{11} \mathrm{~g} / \mathrm{kg} \mathrm{N}$.

${ }^{12} \mathrm{~g} / \mathrm{kg}$ fresh herbage ensiled.

${ }^{13} \mathrm{~g}$ silage DM/kg herbage DM ensiled.

${ }^{14} \mathrm{~g} / \mathrm{kg}$.

when grasses were grown with red clover (grass $+R C$ ) than inorganic $\mathrm{N}$ (grass $+\mathrm{N}$ ).

\section{Fermentation characteristics}

Silage $\mathrm{pH}$ was greatest $(P<0.05)$ for $\mathrm{RC}$ compared with Italian ryegrass-, perennial ryegrass- or timothy-based silages at Cuts 1 (Tables 3 and 4 ) and 2 (Tables 5 and 6), while at
Cut 3 (Tables 7 and 8) TIM/360N had a greater value than $\mathrm{PRG} / 360 \mathrm{~N}$ and both $\mathrm{TIM} / \mathrm{RC}$ and $\mathrm{PRG} / \mathrm{RC}$ had greater values than IRG/RC $(P<0.05)$.

Silage lactic acid concentration at Cut 2 was greater $(P<0.001)$ for perennial ryegrass-based silages than Italian ryegrass- or timothy-based silages as well as RC, while at Cut 3 lactic acid concentration was greater $(P<0.01)$ for 


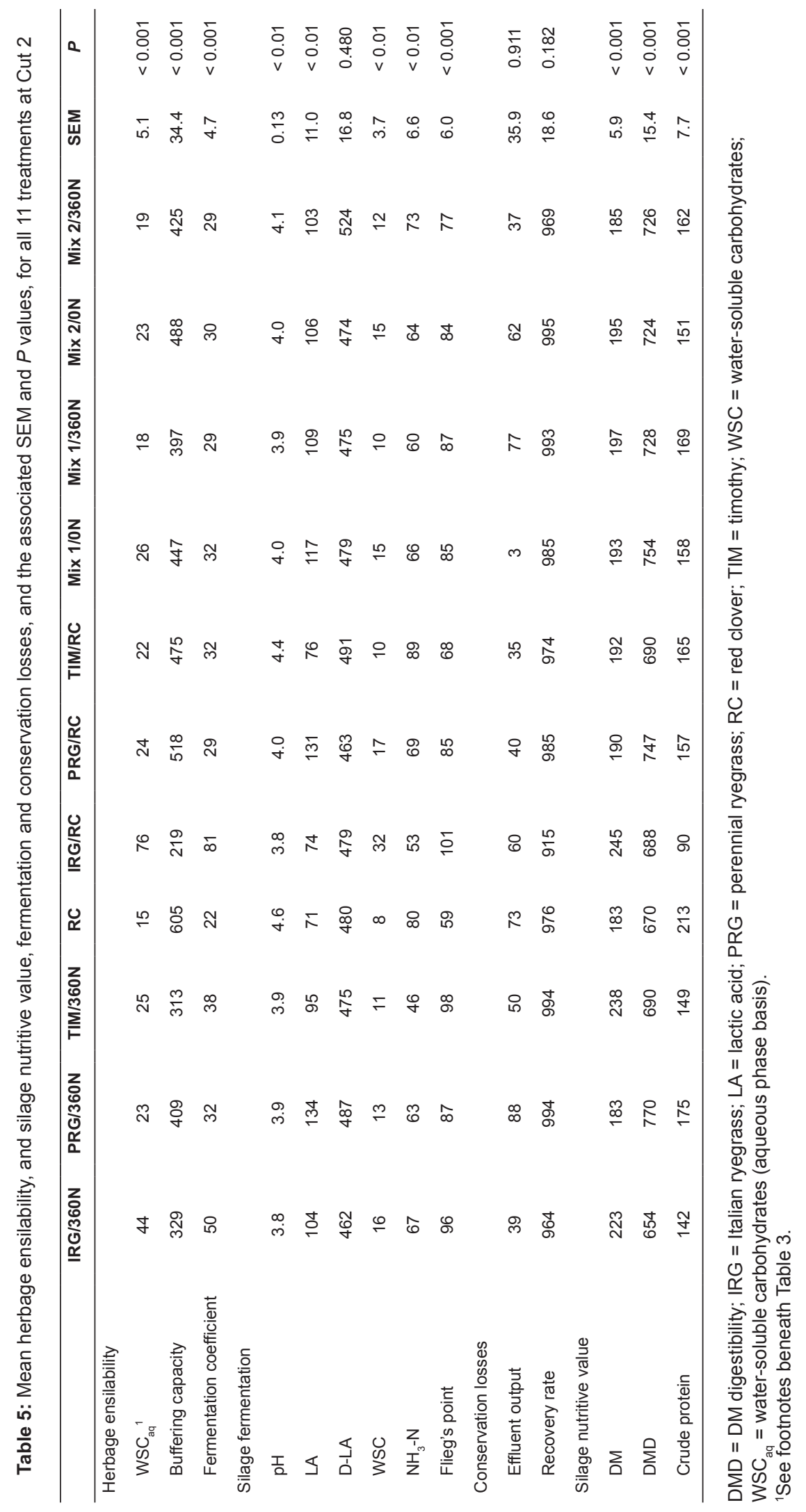


Table 6: SEM and $P$ values for herbage ensilability, and silage nutritive value, fermentation and conservation losses for the main effects and interactions for two groups of treatments at Cut 2

\begin{tabular}{|c|c|c|c|c|c|c|c|c|c|c|c|c|}
\hline \multirow[t]{5}{*}{ Group 1} & \multicolumn{6}{|c|}{1} & \multicolumn{6}{|l|}{4} \\
\hline & & \multicolumn{2}{|l|}{$\mathrm{N}$ source } & \multicolumn{2}{|l|}{ Species } & \multicolumn{2}{|l|}{ Mix } & \multirow[t]{2}{*}{$\mathrm{N}$ rate } & \multicolumn{3}{|c|}{ Mix } \\
\hline & \multicolumn{8}{|c|}{$\mathbf{x}$} & & \multicolumn{3}{|c|}{$x$} \\
\hline & \multicolumn{9}{|c|}{$\mathrm{N}$ source } & \multicolumn{3}{|c|}{$\mathrm{N}$ rate } \\
\hline & SEM & $P$ & SEM & $P$ & SEM & $P$ & SEM & $P$ & SEM & $P$ & SEM & $P$ \\
\hline \multicolumn{13}{|l|}{ Herbage ensilability } \\
\hline $\mathrm{WSC}_{\mathrm{aq}}$ & 3.6 & $<0.001$ & 2.9 & 0.022 & 5.1 & 0.003 & 3.6 & 0.844 & 3.6 & 0.24 & 5.1 & 0.763 \\
\hline Buffering capacity & 24.3 & $<0.001$ & 19.8 & 0.063 & 34.4 & 0.001 & 24.3 & 0.322 & 24.3 & 0.111 & 34.4 & 0.838 \\
\hline Fermentation coefficient & 3.3 & $<0.001$ & 2.7 & 0.068 & 4.7 & $<0.001$ & 3.3 & 0.756 & 3.3 & 0.717 & 4.7 & 0.835 \\
\hline \multicolumn{13}{|l|}{ Silage fermentation } \\
\hline $\mathrm{pH}$ & 0.09 & 0.093 & 0.08 & 0.065 & 0.13 & 0.111 & 0.09 & 0.392 & 0.09 & 0.731 & 0.13 & 0.62 \\
\hline LA & 7.8 & 0.001 & 6.3 & 0.063 & 11 & 0.46 & 7.8 & 0.454 & 7.8 & 0.652 & 11 & 0.836 \\
\hline D-LA & 11.9 & 0.758 & 9.7 & 0.827 & 16.8 & 0.391 & 11.9 & 0.206 & 11.9 & 0.178 & 16.8 & 0.125 \\
\hline WSC & 2.6 & 0.003 & 2.1 & 0.046 & 3.7 & 0.07 & 2.6 & 0.822 & 2.6 & 0.293 & 3.7 & 0.851 \\
\hline $\mathrm{NH} 3-\mathrm{N}$ & 4.7 & 0.508 & 3.8 & 0.037 & 6.6 & 0.001 & 4.7 & 0.428 & 4.7 & 0.844 & 6.6 & 0.226 \\
\hline Flieg's point & 4.2 & 0.034 & 3.5 & 0.067 & 6 & 0.016 & 4.2 & 0.372 & 4.2 & 0.688 & 6 & 0.519 \\
\hline \multicolumn{13}{|l|}{ Conservation losses } \\
\hline Effluent output & 25.4 & 0.827 & 20.7 & 0.643 & 35.9 & 0.636 & 25.4 & 0.791 & 25.4 & 0.5 & 35.9 & 0.178 \\
\hline Recovery rate & 13.1 & 0.023 & 10.7 & 0.105 & 18.6 & 0.561 & 13.1 & 0.714 & 13.1 & 0.636 & 18.6 & 0.384 \\
\hline \multicolumn{13}{|l|}{ Silage nutritive value } \\
\hline DM & 4.2 & $<0.001$ & 3.4 & 0.239 & 5.9 & $<0.001$ & 4.2 & 0.44 & 4.2 & 0.601 & 5.9 & 0.277 \\
\hline DMD & 10.9 & $<0.001$ & 8.9 & 0.618 & 15.4 & 0.194 & 10.9 & 0.31 & 10.9 & 0.436 & 15.4 & 0.383 \\
\hline Crude protein & 5.4 & $<0.001$ & 4.4 & 0.008 & 7.7 & 0.001 & 5.4 & 0.343 & 5.4 & 0.175 & 7.7 & 0.987 \\
\hline
\end{tabular}

$\mathrm{DMD}=\mathrm{DM}$ digestibility; $\mathrm{LA}=$ lactic acid; WSC = water-soluble carbohydrates; WSC $_{\text {aq }}=$ water-soluble carbohydrates (aqueous phase basis). ${ }^{1}$ See footnotes beneath Table 4.

PRG/360N than for RC, PRG/RC and TIM/RC. Furthermore, the proportion of $D$-lactate was greater $(P<0.05)$ for TIM/RC than for PRG/360N.

Italian ryegrass-based silages had a greater $(P<0.01)$ WSC content than perennial ryegrass- and timothy-based silages and $\mathrm{RC}$ at Cuts 1 and 2, with the magnitude of this difference being greater $(P<0.01)$ when each grass was grown with red clover than with inorganic $\mathrm{N}$ at Cut 1 only.

Concentrations of $\mathrm{NH}_{3}-\mathrm{N}$ at Cut 2 were greater $(P<0.05)$ for TIM/RC than for IRG/360N, PRG/360N, TIM/360N, IRG/RC and PRG/RC, while RC was greater $(P<0.05)$ than TIM/360N and IRG/RC. At Cut 3, TIM/360N, PRG/RC and TIM/RC had greater $(P<0.05) \mathrm{NH}_{3}-\mathrm{N}$ concentrations than $\mathrm{PRG} / 360 \mathrm{~N}$, while TIM/360N was greater than IRG/360N, PRG/360N and IRG/RC.

\section{Conservation losses}

Effluent production $(P<0.05)$ was greater for grass $+\mathrm{N}$ than for grass + RC at Cut 1 (Tables 3 and 4), while RC produced more effluent than any other treatment $(P<0.01)$. At Cut 3
(Tables 7 and 8), however, effluent production was greater $(P<0.01)$ for grass $+\mathrm{RC}$ than for grass $+\mathrm{N}$. Silage $\mathrm{DM}$ recovery rates at Cut 1 were greater $(P<0.05)$ for TIM/360N than for PRG/360N, TIM/RC and RC, while at Cut 2 (Tables 5 and 6$)$ DM recovery was greater $(P<0.05)$ for perennial ryegrass- and timothy-based silages than for Italian ryegrassbased silages.

\section{Silage nutritive value}

Silage DM content at Cut 1 (Tables 3 and 4) was greater $(P<0.01)$ for Italian ryegrass-based silages than for RC and at Cut 2 (Tables 5 and 6$)$ it was greater $(P<0.001)$ for IRG/RC and TIM/360N than for TIM/RC, PRG/RC, RC and PRG/360N. Silage DMD at Cut 1 was lower $(P<0.01)$ for RC than for Italian ryegrass-, perennial ryegrass- and timothy-based silages; however, DMD values were greater $(P<0.05)$ for grass $+\mathrm{RC}$ than for grass $+N$. At Cut 2, perennial ryegrass-based silages (PRG/360N and PRG/RC) had greater $(P<0.001)$ values than Italian ryegrass or timothy-based silages (IRG/360, 


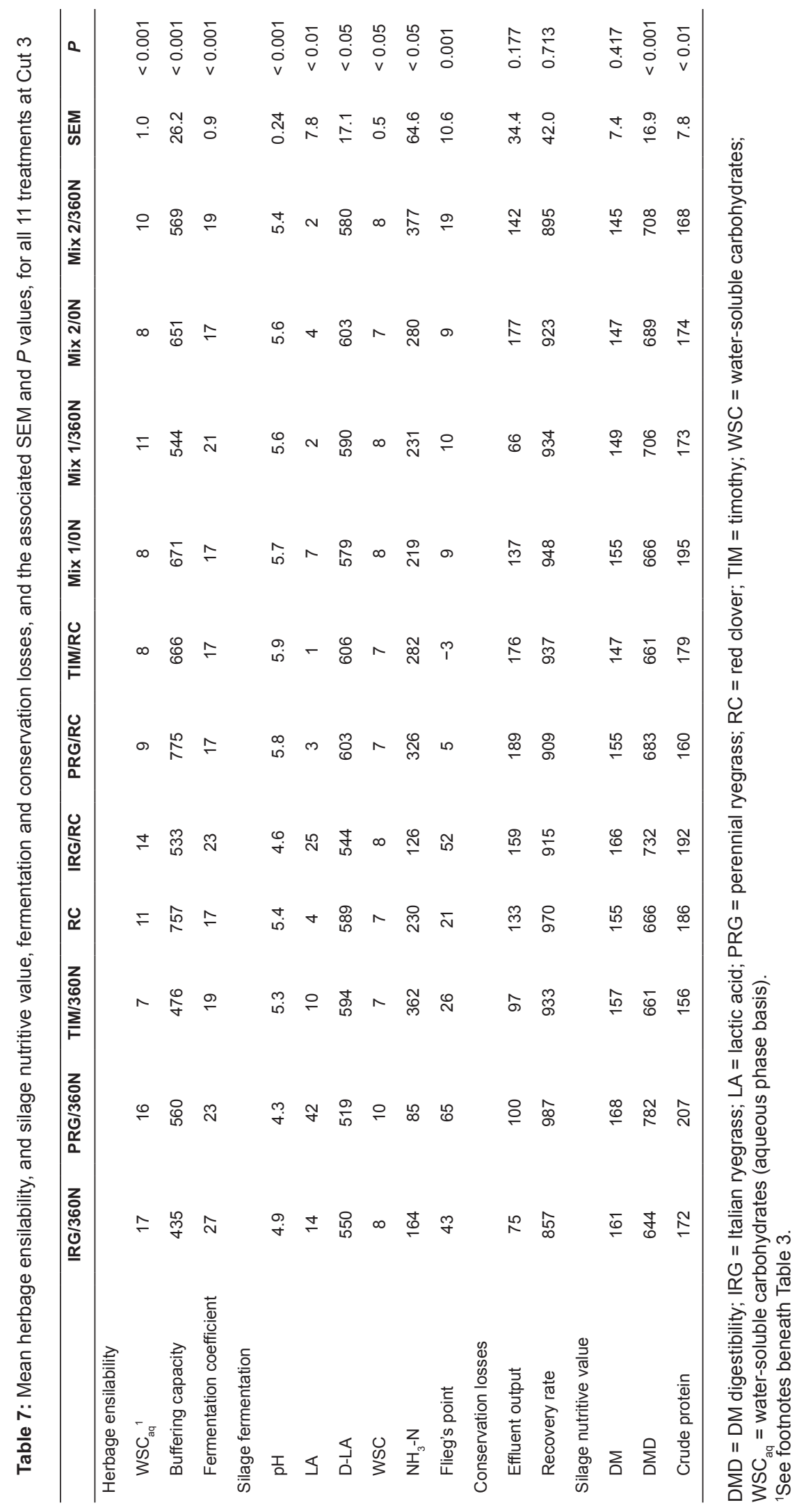




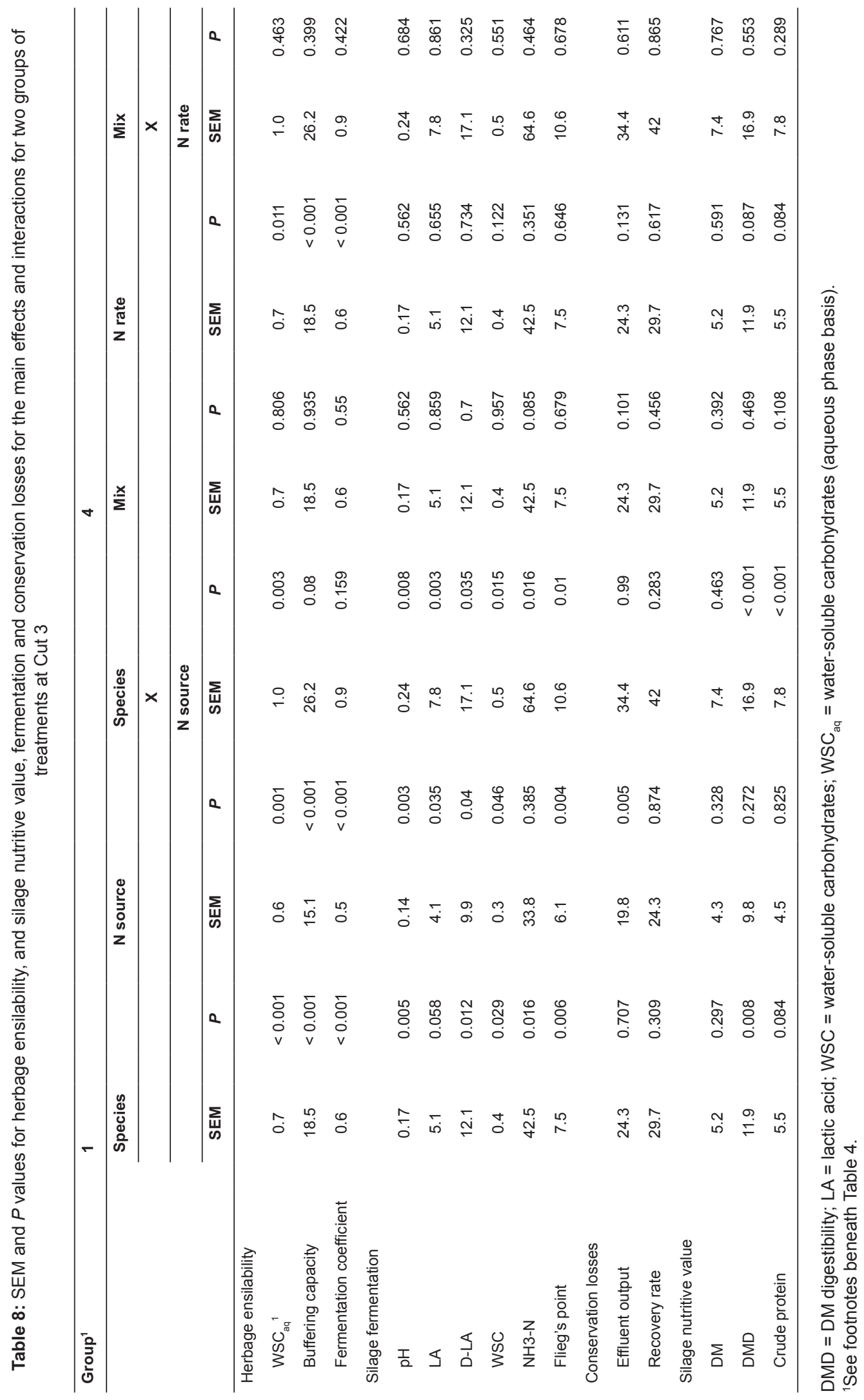


IRG/RC or TIM/360N, TIM/RC, respectively) and RC. At Cut 3 (Tables 7 and 8), PRG/360N had a greater $(P<0.05)$ DMD than TIM/360N which, in turn, was greater than IRG/360N. Furthermore, at Cut 3, PRG/360N had a greater $(P<0.05)$ DMD value than PRG/RC, IRG/360N had a lower $(P<0.05)$ value than IRG/RC, while RC had a lower $(P<0.05) \mathrm{DMD}$ value than both $P R G / 360 N$ and IRG/RC.

The silage CP content was greater $(P<0.01)$ for RC than for all other treatments at Cuts 1 and 2. Furthermore, at Cut 1, the silage CP content was greater $(P<0.01)$ for timothy than for Italian ryegrass-based silages, while grass $+\mathrm{N}$ had greater $(P<0.001)$ values than grass $+\mathrm{RC}$. The silage CP content at Cut 2 was greater for PRG/360N than for TIM/360N and IRG/360N; however, both PRG/RC and TIM/RC had greater values than IRG/RC $(P<0.001)$. At Cut $3, \mathrm{PRG} / 360 \mathrm{~N}$ had a greater $(P<0.01) \mathrm{CP}$ content than $\mathrm{PRG} / \mathrm{RC}$ and $\mathrm{TIM} / 360 \mathrm{~N}$, while IRG/RC was greater than PRG/RC, $P R G / 360 N$ was greater than $P R G / R C$, and TIM/RC was greater than TIM/360N $(P<0.05)$.

Perennial ryegrass at $360 \mathrm{~N}$ versus binary- and multispecies mixtures at $0 N$ (Group 2; PRG/360N, PRG/RC, Mix $1 / 0 N$ and Mix 2/0N)

\section{Herbage ensilability}

Herbage WSC $_{a q}$ at Cut 3 (Tables 7 and 8) was greatest $(P<0.01)$ for PRG/360N. Buffering capacity at Cut 2 (Tables 5 and 6) was greater $(P<0.01)$ for $P R G / R C$ than for $P R G / 360 N$, while at Cut $3 \mathrm{PRG} / \mathrm{RC}$ had the greatest $(P<0.01)$ buffering capacity. Furthermore, at Cut 3 , Mix $1 / 0 \mathrm{~N}$ and Mix $2 / 0 \mathrm{~N}$ were greater $(P<0.01)$ than $\mathrm{PRG} / 360 \mathrm{~N}$.

\section{Fermentation characteristics}

There was no difference $(P>0.05)$ in $\mathrm{pH}$ or WSC content between species except at Cut 3 (Tables 7 and 8) where PRG/360N had the lowest $(P<0.001) \mathrm{pH}$ value and the highest $(P<0.05)$ WSC content.

At Cut 3, lactic acid concentration was greatest $(P<0.01)$ for $\mathrm{PRG} / 360 \mathrm{~N}$, while at the same cut D-lactate as a proportion of lactic acid was least $(P<0.01)$ in $\mathrm{PRG} / 360 \mathrm{~N}$ silage. Furthermore, at Cut 3, $\mathrm{NH}_{3}-\mathrm{N}$ concentrations were greater for $\mathrm{PRG} / \mathrm{RC}$ and Mix 2/0N $(P<0.05)$ than for PRG/360N.

\section{Conservation losses}

Effluent production was greater $(P<0.05)$ for $\mathrm{PRG} / 360 \mathrm{~N}$ than for PRG/RC and Mix 2/ON at Cut 1 (Tables 3 and 4), while DM recovery rates were greater $(P<0.05)$ for Mix $1 / 0 \mathrm{~N}$ and Mix $2 / 0 \mathrm{~N}$ than $\mathrm{PRG} / 360 \mathrm{~N}$ at the same cut.

Silage nutritive value

Silage DMD values at Cut 1 (Tables 3 and 4) were greater $(P<0.01)$ for $P R G / R C$ and Mix $2 / 0 N$ than for PRG/360N. At
Cut 2 (Tables 5 and 6 ), PRG/360N had greater $(P<0.01)$ values than Mix $2 / 0 \mathrm{~N}$, while $P R G / 360 \mathrm{~N}$ had the greatest $(P<0.01)$ DMD at Cut 3 (Tables 7 and 8).

At Cut 1 , the silage $\mathrm{CP}$ content was greatest $(P<0.01)$ for PRG/360N, while at Cuts 2 and 3 the values for PRG/360N were greater $(P<0.01)$ than for Mix $2 / 0 \mathrm{~N}$. Furthermore, at Cut $3 \mathrm{PRG} / 360 \mathrm{~N}$, Mix $1 / 0 \mathrm{~N}$ and Mix $2 / 0 \mathrm{~N}$ had greater $(P<0.01)$ $\mathrm{CP}$ contents than PRG/RC.

\section{Perennial ryegrass versus two multi-species mixtures at $360 N$ (Group 3; PRG/360N, Mix 1/360N and Mix 2/360N)}

Herbage ensilability

There was no difference in the ensilability indices of each species treatment except at Cut 3 (Tables 7 and 8) where the WSC $_{\text {aq }}$ content of PRG/360N was greater $(P<0.01)$ than that of Mix $1 / 360 \mathrm{~N}$ and Mix 2/360N.

\section{Fermentation characteristics}

There was no treatment effect on silage $\mathrm{pH}$ or WSC content except at Cut 3 (Tables 7 and 8) where PRG/360N had the lowest $(P<0.01) \mathrm{pH}$ and a greater $(P<0.01)$ WSC content than Mix $1 / 360 N$. Furthermore, there was no treatment effect on the concentration of $\mathrm{LA}$ and $\mathrm{NH}_{3}-\mathrm{N}$ at Cuts 1 (Tables 3 and 4 ) and 2 (Tables 5 and 6 ). At Cut 3, however, lactic acid concentration was greatest $(P<0.01)$ for PRG/360N while the proportion of D-lactate was greater for Mix $1 / 360 \mathrm{~N}$ and Mix 2/360N than for PRG/360N.

\section{Conservation losses}

Silage effluent production was not different between treatments at any cut; however, the DM recovery rate was greater $(P<0.05)$ for Mix 2/360N than for PRG/360N at Cut 1 (Tables 3 and 4).

\section{Silage nutritive value}

Silage DMD was greater $(P<0.05)$ for $\mathrm{PRG} / 360 \mathrm{~N}$ than for Mix $2 / 360 \mathrm{~N}$ at Cut 2 (Tables 5 and 6), and greater than for both Mix $1 / 360 \mathrm{~N}$ and Mix $2 / 360 \mathrm{~N}$ at Cut 3 , while the silage CP content was greatest $(P<0.01)$ for $\mathrm{PRG} / 360 \mathrm{~N}$ at Cut 3 (Tables 7 and 8 ).

\section{Multi-species mixtures at $0 \mathrm{~N}$ or $360 \mathrm{~N}$ (Group 4; Mix 1/0N, Mix 2/0N, Mix 1/360N and Mix 2/360N)}

\section{Herbage ensilability}

There was no effect of species mixture or rate of inorganic $N$ on the ensilability of herbage except at Cut 3 (Tables 7 and 8) where WSC $_{\text {aq }}$ was lower $(P<0.05)$ and buffering capacity was greater $(P<0.001)$ for $0 \mathrm{~N}$ than for $360 \mathrm{~N}$.

\section{Fermentation characteristics}

There were no effects $(P>0.05)$ of treatment on fermentation characteristics. 


\section{Conservation losses}

Effluent production was greater for herbage-receiving $360 \mathrm{~N}$ than $0 \mathrm{~N}$ at Cut 1 (Tables 3 and 4).

\section{Silage nutritive value}

There was no main or interaction effect $(P>0.05)$ on the DM, DMD or CP content of silages produced from the four treatments at any cut, except for the CP content at Cut 1 (Tables 3 and 4) where the main effect value was greater $(P<0.01)$ for $360 \mathrm{~N}$ than for $0 \mathrm{~N}$.

\section{Discussion}

In Ireland, herbage harvested from grassland swards sometimes receives relatively little field wilting prior to ensiling due to unsuitable weather conditions. The range of mean DM values of $116-257 \mathrm{~g} / \mathrm{kg}$ for the 33 unwilted herbages ensiled (three cuts of 11 treatments) reflects the prevailing moist cropgrowing conditions, and agrees with previous values reported by Keating \& O'Kiely (2000a), Conaghan et al. (2012) and Clavin et al. (2017), while the corresponding values for WSC $_{\text {aq }}$ (7-76 g/L), buffering capacity (219-775 mEq/ $\mathrm{kg}$ DM) and fermentation coefficient (17-81) represent a broad range in these crop ensilability indicators. Weissbach \& Honig (1996) indicated that herbages with fermentation coefficients above 35 were likely to preserve satisfactorily as silage, provided either their nitrate content exceeded $0.5 \mathrm{~g} / \mathrm{kg}$ DM or their culturable lactic acid bacteria numbers exceeded $10^{5} \mathrm{cfu} / \mathrm{g}$. Under Irish climatic conditions, grassland swards managed for commercial silage production commonly reach these nitrate (Muck et al., 1991; Lorenzo \& O'Kiely, 2008; Navarro-Villa et al., 2011) and lactic acid bacteria (Moran et al., 1990) thresholds.

The relationship between the fermentation coefficient and Flieg index values for the 132 herbage-silage experimental units was as follows (Figure 1):

Flieg index $=((5.65 \times$ fermentation coefficient $)-(0.046$

$$
\left.\left.\times(\text { fermentation coefficient })^{2}\right)\right)-61.1,\left(\mathrm{R}^{2}=0.66\right)
$$

This indicates that factors other than DM, WSC and buffering capacity influenced the fermentation outcomes. These could include, in individual cases, sub-optimal nitrate content or lactic acid bacteria numbers (Weissbach \& Honig, 1996) as well as, among a range of other factors, ambient temperature, speed of availability of WSC to epiphytic microorganisms, content of other fermentable substrate, numbers of other indigenous microorganisms and the speed and extent of effluent outflow. Overall, however, the mean Flieg index point values for Cuts 1-3 of 70,84 and 23 , respectively, highlight the markedly poorer

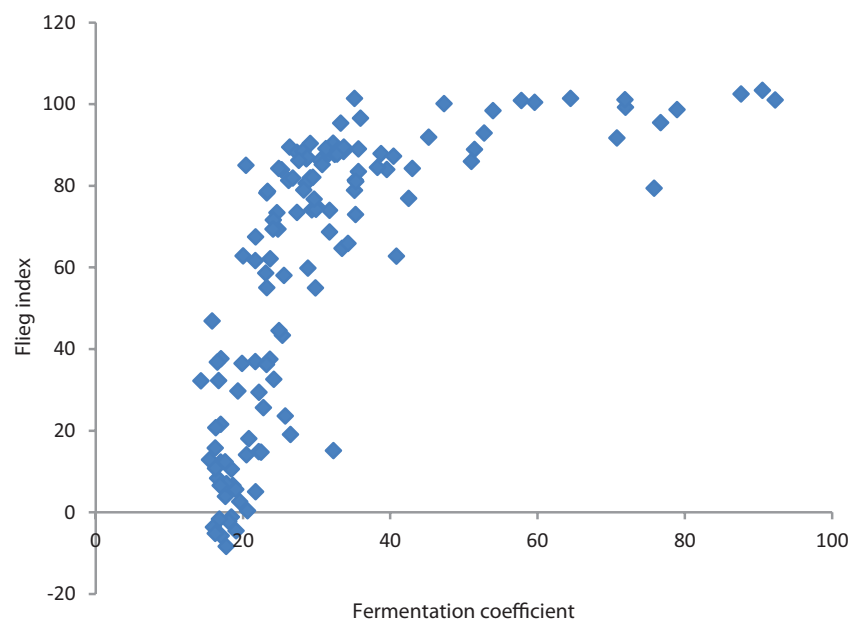

Figure 1. The relationship between the fermentation coefficient and the Flieg index values for the 132 herbage-silage experimental units.

preservation characteristics at Cut 3 and this, in turn, was signposted by the particularly low fermentation coefficients of Cut 3 herbages. In contrast, however, the generally better preservation characteristics of Cut 2 compared with Cut 1 silages were not indicated by their corresponding fermentation coefficient values.

Perennial ryegrass, Italian ryegrass and timothy receiving inorganic N or grown with red clover (Group 1; PRG/360N, IRG/360N, TIM/360N, PRG/RC, IRG/RC, TIM/RC and RC)

The mean annual WSC $_{\text {aq }}$ and buffering capacity values of 31, 22 and $14 \mathrm{~g} / \mathrm{L}$ and 235, 272 and $257 \mathrm{mEq} / \mathrm{kg} \mathrm{DM}$ for IRG/360N, PRG/360N and TIM/360N, respectively, are of similar rankings of these species for both variables to those reported by Wilson \& Collins (1980). The combined effects of these two ensilability indices, in turn, are encapsulated by the single fermentation coefficient index of Weissbach \& Honig (1996) where the corresponding values of 42,33 and 27 suggest IRG/360N was most likely and TIM/360N was least likely to preserve satisfactorily during ensilage. However, these mean annual relativities among grass species were not consistent across cuts. The differences in mean WSC across cuts within each grass species likely reflect the direct and indirect effects of the prevailing weather on both DM and WSC values (Deinum, 1984), whereas the general increase in buffering capacity from Cut 1 through to Cut 3 repeats a seasonal pattern previously reported by Muck et al. (1991) and can be attributed, at least in part, to the concurrent increase in CP content.

The lower WSC $_{\text {aq }}$ content recorded for RC than for IRG/360N and $P R G / 360 N$ and its consistently greater buffering capacity than any of the grass monocultures is as expected and agrees with the findings of King et al. (2012b). Consequently, RC had 
a lower overall fermentation coefficient (20) than the grass monocultures. The low $\mathrm{WSC}_{\mathrm{aq}}$ contents for RC are partly due to its lower DM content (Dewhurst et al., 2009) and also to some of their non-structural carbohydrates being stored as starch rather than as WSC (Buxton \& O'Kiely, 2003).

The expectation that both the $\mathrm{WSC}_{\mathrm{aq}}$ and buffering capacity of the binary mixtures might be intermediate between the values for the grass and red clover monocultures did not occur, suggesting these traits differed in either or both constituent species compared with when in monoculture. This phenomenon was previously reported by Moloney et al. (2020a). It may be, for example, that changes in the amount and/or timing of $\mathrm{N}$ provision by red clover to the grass species compared with $\mathrm{N}$ provision from inorganic fertiliser when in monoculture could have resulted in considerably greater WSC $_{\mathrm{aq}}$ contents and lower buffering capacities for the grasses when in binary mixtures. Both Conaghan et al. (2012) and Clavin et al. (2017) have demonstrated that lower rates of provision of inorganic $\mathrm{N}$ increased grass $\mathrm{WSC}_{\mathrm{aq}}$ and reduced its buffering capacity. Consequently, the findings by Moloney et al. (2020b) of mean annual red clover contents in IRG/RC, $P R G / R C$ and $T I M / R C$ of 25,55 and $54 \%$, respectively, may explain why the effects of changing from grass plus inorganic $\mathrm{N}$ to the corresponding grass plus red clover binary mixture were more dramatic with IRG/RC than with $\mathrm{PRG} / \mathrm{RC}$ or $\mathrm{TIM} /$ $\mathrm{RC}$ at both Cuts 1 and 2 .

The absence of a difference in the effluent outflow between the three grass species monocultures is in agreement with the study by King et al. (2013), while the trend for the red clover monoculture to produce a greater output of effluent was previously identified by King et al. (2012a) and can be attributed to the characteristically low DM content of red clover. Thus, the absence of a difference in the effluent outflow between grass plus inorganic $\mathrm{N}$ and grass plus red clover treatments is likely due to changed characteristics of grass when in binary mixture with red clover compared with when fertilised with inorganic N. For example, if grass in the binary mixture had a greater DM content than when fertilised with inorganic $\mathrm{N}$, the expected reduced effluent outflow from grass could compensate for the greater effluent outflow of red clover.

King et al. (2013) reported mean DM recovery rates for Italian ryegrass, perennial ryegrass and timothy silages of 888,918 and $936 \mathrm{~g} / \mathrm{kg}$, respectively, with King et al. (2012a) reporting a corresponding recovery for red clover silages of $874 \mathrm{~g} / \mathrm{kg}$. Although the recovery rates for comparable treatments in the current experiment were not statistically different, the numerical trend observed (mean values of 897, 938, 960 and $896 \mathrm{~g} / \mathrm{kg}$, respectively) was similar to that in the study by King et al. (2013) The absence of a difference in the recovery rate between the binary mixtures and the corresponding grass monoculture treatments was probably strongly influenced by the simultaneous absence of an effect on the effluent outflow discussed earlier.

Silage nutritive value is primarily a product of the nutritive value of the herbage ensiled and the efficiency of the ensilage process (Dulphy \& Demarquilly, 1991). Comparison of the three grass monoculture silages to their respective preensiled herbages (Moloney et al., 2020a) shows a decline in DMD values at Cuts 1 and 3 where conservation losses were greatest but no such decline at Cut 2 where preservation and recovery rates were more efficient. The absence of a consistent difference in the change in DMD among the three grass species treatments or between these grass and red clover treatments is in agreement with the study by King et al. (2012a) and King et al. (2013). Thus, for silages at Cuts 2 and 3 , the greater DMD observed for PRG/360N than for IRG/360N, $T I M / 360 N$ and RC, and the absence of a difference among the latter three monoculture treatments, derive mainly from their relative values at the time of ensiling. Similarly, as there was no clear-cut difference between grass plus inorganic $\mathrm{N}$ and grass plus red clover treatments in pre-ensilage DMD or a difference in changes in DMD during ensilage, it was therefore to be expected that there would be no clear-cut difference in silage DMD.

\section{Perennial ryegrass at $360 \mathrm{~N}$ versus binary- and multi- species mixtures at ON (Group 2; PRG/360N, PRG/RC, Mix 1/0N and Mix 2/0N)}

The relatively similar fermentation coefficients for PRG/RC, Mix $1 / 0 \mathrm{~N}$ and Mix 2/ON suggest that introducing timothy and white clover into a mixture with perennial ryegrass and red clover (i.e. $\mathrm{PRG} / \mathrm{RC}$ vs. Mix $1 / 0 \mathrm{~N}$ ) and then subsequently replacing white clover by ribwort plantain and chicory (i.e. Mix $1 / 0 \mathrm{~N}$ vs. Mix $2 / 0 \mathrm{~N}$ ) did not measurably alter the combined calculated impacts on ensilability of herbage DM, WSC and buffering capacity. This is surprising as the evidence from the monoculture treatments is that timothy, for example, would have an inferior fermentation coefficient to perennial ryegrass because of its lower WSC content (King et al., 2012b) and that white clover frequently has a particularly low DM content (Frame \& Newbould, 1986). However, the fermentation coefficients for the individual species sampled from Mix 1 and Mix 2 (Table 9), albeit when grown with $120 \mathrm{~kg} \mathrm{~N} /$ ha per year, indicate that timothy growing in multi-species mixtures had a slightly greater fermentation coefficient than a perennial ryegrass monoculture, while red and white clovers had similar fermentation coefficients to each other albeit both were lower than the grasses. The similarly low fermentation coefficients for both herbs and white clover together with their usually relatively small proportions of the harvested biomass (Moloney et al., 2020b) explain the muted impact of replacing white clover by herbs.

Perennial ryegrass monocultures managed with the input of inorganic $\mathrm{N}$ fertiliser have been the predominant grassland 
Table 9: Mean chemical composition of individual species within Mix 1 and Mix 2 at Cuts 1-3 pre-ensiling

\begin{tabular}{|c|c|c|c|c|c|c|c|}
\hline Species & & Perennial ryegrass ${ }^{1}$ & Timothy $^{2}$ & Red clover ${ }^{2}$ & White clover ${ }^{2}$ & Ribwort plantain ${ }^{2}$ & Chicory ${ }^{2}$ \\
\hline & Cut & & & & & & \\
\hline \multirow[t]{3}{*}{$\mathrm{WSC}_{\mathrm{aq}}{ }^{3}$} & 1 & 24 & 61 & 22 & 21 & 16 & 14 \\
\hline & 2 & 55 & 28 & 19 & 12 & 24 & 25 \\
\hline & 3 & 28 & 50 & 23 & 18 & 31 & 33 \\
\hline \multirow[t]{3}{*}{ Buffering capacity ${ }^{4}$} & 1 & 265 & 264 & 544 & 526 & 381 & 469 \\
\hline & 2 & 317 & 261 & 589 & 557 & 467 & 473 \\
\hline & 3 & 456 & 338 & 649 & 582 & 473 & 513 \\
\hline \multirow[t]{3}{*}{$\mathrm{WSC}^{5}$} & 1 & 131 & 177 & 120 & 120 & 110 & 117 \\
\hline & 2 & 216 & 102 & 89 & 73 & 91 & 128 \\
\hline & 3 & 140 & 136 & 100 & 105 & 109 & 166 \\
\hline \multirow[t]{3}{*}{$\mathrm{DM}^{5}$} & 1 & 152 & 257 & 152 & 150 & 125 & 107 \\
\hline & 2 & 203 & 213 & 180 & 139 & 206 & 161 \\
\hline & 3 & 168 & 267 & 184 & 145 & 220 & 165 \\
\hline \multirow[t]{3}{*}{ Fermentation coefficient ${ }^{6}$} & 1 & 42 & 62 & 27 & 27 & 28 & 24 \\
\hline & 2 & 58 & 43 & 26 & 21 & 31 & 31 \\
\hline & 3 & 33 & 48 & 27 & 24 & 34 & 34 \\
\hline
\end{tabular}

WSC = water-soluble carbohydrates; WSC $_{\text {aq }}=$ water-soluble carbohydrates (aqueous phase basis).

${ }^{1}$ Samples were taken from monoculture of diploid perennial ryegrass with an intermediate heading date, grown with $120 \mathrm{~kg} N / \mathrm{ha}$ per year (Moloney et al., 2020a).

${ }^{2}$ Samples were taken from Mix 1 and Mix 2 receiving $120 \mathrm{~kg} \mathrm{~N} / \mathrm{ha}$ per year (Moloney et al., 2020a).

${ }^{3} \mathrm{~g} / \mathrm{L}$.

${ }^{4} \mathrm{mEq} / \mathrm{kg} \mathrm{DM}$.

${ }^{5} \mathrm{~g} / \mathrm{kg}$.

${ }^{6}$ Weissbach \& Honig (1996).

swards sown in Ireland for several decades. It is interesting that the fermentation coefficients of PRG/RC, Mix 1/ON and Mix 2/0N were only slightly lower than for this industry standard (PRG/360N). However, this scale of difference was small compared, for example, to the differences for all treatments between high values for coefficients at Cut 1 and low values at Cut 3 .

When compared with pre-ensilage DMD values at Cuts 1 and 3 , the corresponding lower post-ensilage values for the four treatments reflect the greater output of effluent and poorer fermentation outcome at those cuts relative to Cut 2 where there was no such decline in DMD. As there was no consistent difference in DMD between these treatments preensilage (Moloney et al. 2020a) and no consistent difference in the efficiency of ensilage, it is not surprising that no clearcut differences in silage DMD emerged.

The general trend that occurred at each cut for PRG/360N to have greater $\mathrm{CP}$ content than the other three treatments may seem surprising as the direct and indirect effects of the legumes in the binary and multi-species mixture treatments might have been expected to elevate their CP content. However, as previously shown by Keating \& O'Kiely (2000b), Conaghan et al. (2012) and Clavin et al. (2017), high inputs of inorganic N can produce grasses with relatively high CP values.

\section{Perennial ryegrass versus two multi-species mixtures at} $360 N$ (Group 3; PRG/360N, Mix $1 / 360$ N and Mix 2/360N)

The trend that was evident at each cut of both Mix $1 / 360 \mathrm{~N}$ and Mix 2/360N having a numerically lower fermentation coefficient than PRG/360N was caused mainly by their lower WSC $_{\mathrm{ac}}$ values. As grass was the dominant functional group in Mix $1 / 360 \mathrm{~N}$ and Mix $2 / 360 \mathrm{~N}$ (grass contributed $84 \%$ and $72 \%$ of biomass across all cuts, respectively) and as timothy in these mixtures expressed relatively high fermentation coefficients as did a perennial ryegrass monoculture (Table 9), then the lower coefficients of both mixtures were due to the negative effects of both the legume and herb functional groups.

The trend for the Mix 1 and Mix 2 silages to have lower overall DMD values than the perennial ryegrass treatment (across cut mean values of 705,703 and $736 \mathrm{~g} / \mathrm{kg}$, respectively), although not consistent across cuts, reflected their relative values preensilage (717, 721 and $746 \mathrm{~g} / \mathrm{kg}$, respectively; Moloney et al., 2020a), with the reductions in the absolute values during ensilage reflecting the effects of conservation losses. 
Multi-species mixtures at $0 \mathrm{~N}$ or $360 \mathrm{~N}$ (Group 4; Mix 1/0N, Mix 2/ON, Mix 1/360N and Mix 2/360N)

Applying inorganic $\mathrm{N}$ to Mix 1 changed the mean annual content of grass from 62 to $84 \%$ of herbage biomass and of legume from 38 to $16 \%$. Changes to the grass, legume and herb contents in Mix 2 were from 54 to $72 \%, 22$ to $8 \%$ and 24 to $20 \%$, respectively (Moloney et al., 2020b). Despite these effects of inorganic $\mathrm{N}$ on botanical composition and possibly also on other traits within individual herbage species present (Table 9 and Moloney et al., 2020a), the consistent absence of a significant interaction between herbage species mixture and rate of inorganic $\mathrm{N}$ applied indicates that species mixture effects on herbage ensilability, silage fermentation, conservation loss and silage nutritive value traits behaved similarly at both rates of inorganic $\mathrm{N}$.

With the exception of Mix 2/0N at Cut 1, both sward species mixtures exhibited lower fermentation coefficients than the threshold value of 35 identified by Weissbach \& Honig (1996) as being necessary to exceed in order to ensure successful preservation of ensiled unwilted herbage. The values at Cut 3 therefore appeared particularly challenging. Overall, the low values reflect the effects of the lower coefficients for legume and herb functional groups compared with grasses, as shown in Table 9. In addition, where inorganic $\mathrm{N}$ was applied it is likely that this had an effect of reducing WSC $_{\text {aq }}$ and increasing buffering capacity values for the grass species present (Keating \& O'Kiely, 2000a; Conaghan et al., 2012; Clavin et al., 2017), and this would have largely cancelled the simultaneous reduction in the proportion of the nongrass functional groups present. The similar fermentation coefficients for the two sward species mixture treatments was a product of there being no significant differences between them in $\mathrm{WSC}_{\mathrm{aq}}$ or buffering capacity values at any cut. This, in turn, indicates that the replacement of white clover $(8-30 \%$ of biomass; mean fermentation coefficient of 24$)$ by herbs $(12-30 \%$ of biomass; mean fermentation coefficient of 30) did not measurably impact the fermentation coefficient. It is noteworthy that within each functional group the fermentation coefficients for the two constituent species were generally comparably high (both grasses) or low (both legumes and both herbs).

Both Pahlow et al. (2003) and Clavin et al. (2017) suggested that the ensilability index thresholds that would indicate a likelihood of satisfactory silage preservation appear to differ for grasses and legumes. In the case of red clover, for example, Clavin et al. (2017) proposed explanations for its better than expected preservation such as a greater quantity of fermentable substrate being available than measured in WSC, the beneficial effects it derives from polyphenol oxidase and a lower water activity compared with grass of the same DM content.
As the herbage from both sward species mixture treatments had similar pre-ensilage DMD and $\mathrm{CP}$ values and both treatments underwent similar DM recovery rates and standards of preservation during ensilage, the generally similar DMD and CP of their silages were to be expected. This outcome for DMD also agrees with the finding that the pre-ensilage DMD of white clover was intermediate between that of ribwort plantain and chicory (799 vs. 694 and $832 \mathrm{~g} /$ $\mathrm{kg}$, respectively; Moloney et al., 2020a) such that replacing this legume by the two herbs caused no net change in value. However, this rationale does not explain the similar CP for Mix 1 and Mix 2 silages as the pre-ensilage values for white clover, ribwort plantain and chicory were 233, 134 and $153 \mathrm{~g} / \mathrm{kg} \mathrm{DM}$, respectively (Moloney et al. 2020a).

\section{Practical implications}

Numerous factors such as annual and seasonal herbage yield and nutritive value, and sward persistence, impact on the suitability of different herbage species and cultivars in grassland swards managed for silage production. Other studies from the project with which this experiment is associated have examined these factors (Moloney et al., 2020a; 2020b). The current study demonstrates that under favourable ensiling conditions (e.g. Cut 2) unwilted grass-red clover binary mixtures and multi-species mixtures can preserve satisfactorily as silage, comparable to a perennial ryegrass monoculture receiving inorganic $\mathrm{N}$ fertiliser. However, when ensiled under more challenging crop conditions (e.g. Cut 3), it appears the binary mixtures and multi-species mixture swards have a greater requirement for an adequate rapid wilt and/or sufficient effective preservative to be evenly applied. Future research should quantify the ease of successfully wilting binary mixture and multi-species mixture swards under practical field conditions, as well as quantifying conservation losses in the field and during ensilage/feedout, and conservation efficiency responses to contrasting additives. Furthermore, the energy and protein values of efficiently conserved silages and the corresponding effects on performance and meat or milk quality should be assessed with appropriate ruminants.

The results of this study suggest that the thresholds of herbage ensilability indices developed to predict the relative ease of successfully preserving grass as silage will need to be adjusted for mixtures containing species from outside of the grass functional group.

\section{Conclusions}

Estimation of the ensilability of binary mixtures and the preservation of their resultant silages need to be based on 
direct analysis of representative binary mixture samples rather than being predicted from measured values for the component species when in monoculture. A major factor impacting negatively on the silage preservation challenge for any of the binary mixtures was the proportion of red clover present.

The broadly similar herbage ensilability and silage fermentation characteristics of PRG/RC, Mix 1/0N and Mix 2/0N suggest that the inclusion of timothy and white clover with perennial ryegrass and red clover (PRG/RC vs. Mix $1 / 0 \mathrm{~N}$ ) or the replacement of white clover by ribwort plantain and chicory (Mix 1/0N vs. Mix 2/0N) did not negatively affect these traits. There was a trend under difficult ensiling conditions, however, for the reference treatment PRG/360N to be somewhat less difficult to preserve than PRG/RC, Mix $1 / 0 \mathrm{~N}$ and Mix $2 / 0 \mathrm{~N}$. This same trend was evident when comparing PRG/360N to Mix $1 / 360 N$ and Mix 2/360N.

Despite the application of inorganic $\mathrm{N}$ to Mix 1 and Mix 2 markedly increasing their grass contents and correspondingly reducing their legume contents, this had relatively little impact on herbage ensilability or silage preservation characteristics. This appeared to be due to expected positive impacts of a reduction in the content of legumes being cancelled by corresponding negative impacts of inorganic $\mathrm{N}$ on grass ensilability and on its resultant fermentation during ensilage.

\section{Acknowledgements}

The authors acknowledge the technical input of B. Weldon, the field plot and ensilage operations undertaken by G. Costello and the Grange farm staff, the chemical analyses by the Grange Laboratories staff, and the advice of J. Finn, Teagasc, Johnstown Castle, Co. Wexford, Ireland in designing the two multi-species mixtures. The technical assistance of R. Fritch and S. Higgins is also acknowledged. Funding was provided by the Department of Agriculture, Food and the Marine through the Research Stimulus Fund (RSF 11/5/147).

\section{References}

AOAC. 1990. "Official methods of analysis". Association of Analytical Chemists, Arlington, VA, USA.

Barry, T.N. 1998. The feeding value of chicory (Cichorium intybus) for ruminant livestock. The Journal of Agricultural Science 131: 251-257.

Bélanger, G., Michaud, R., Jefferson, P.G., Tremblay, G.F. and Brégard, A. 2001. Improving the nutritive value of timothy through management and breeding. Canadian Journal of Plant Science 81: 577-585.
Black, A.D., Laidlaw, A.S., Moot, D.J. and O'Kiely, P. 2009. Comparative growth and management of white and red clovers. Irish Journal of Agricultural and Food Research 48: 149-166.

Burns, G.A., O'Kiely, P., Grogan, D., Watson, S. and Gilliland, T.J. 2015. Comparison of herbage yield, nutritive value and ensilability traits of three ryegrass species evaluated for the Irish Recommended List. Irish Journal of Agricultural and Food Research 54: 31-40.

Buxton, D.R. and O'Kiely, P. 2003. Preharvest plant factors affecting ensiling. In: "Silage Science and Technology", (eds. D.R. Buxton, R.E. Muck and J.H. Harrison), American Society of Agronomy, Crop Science Society of America, Soil Science Society of America, Madison, WI.

Clavin, D., Crosson, P., Grant, J. and O'Kiely, P. 2017. Red clover for silage: management impacts on herbage yield, nutritive value, ensilability and persistence, and relativity to perennial ryegrass. Grass and Forage Science 72: 414-431.

Conaghan, P., O'Kiely, P., Halling, M.A., O'Mara, F.P. and Nesheim, L. 2012. Yield and quality response of perennial ryegrass selected for high concentration of water-soluble carbohydrate to nitrogen application rate. Crop Science 52: 2839-2851.

Copani, G., Ginane, C., Le Morvan, A. and Niderkorn, V. 2014. Bioactive forage legumes as a strategy to improve silage quality and minimise nitrogenous losses. Animal Production Science 54: 1826-1829.

Deak, A., Hall, M.H. and Sanderson, M.A. 2007. Production and nutritive value of grazed simple and complex forage mixtures. Agronomy Journal 99: 814-821.

Deinum, B. 1984. Chemical composition and nutritive value of herbage in relation to climate. The impact of climate on grass production and quality, H. Riley \& AO Skjelvag. Proceedings of the 10th General Meeting of the European Grassland Federation. As, Norway, pages 338-350.

Dewhurst, R.J., Fisher, W.J., Tweed, J.K. and Wilkins, R.J. 2003. Comparison of grass and legume silages for milk production. 1. Production responses with different levels of concentrate. Journal of Dairy Science 86: 2598-2611.

Dewhurst, R.J., Delaby, L., Moloney, A., Boland, T. and Lewis, E. 2009. Nutritive value of forage legumes used for grazing and silage. Irish Journal of Agricultural and Food Research 48: 167-187.

Dulphy, J.P. and Demarquilly, P. 1991. Digestibility and voluntary intake of conserved forages. Landbaumforschung Volkerode Sonderheft: 140-160.

Ergon, A.., Kirwan, L., Fystro, G., Bleken, M.A., Collins, R.P. and Rognli, O.A. 2017. Species interactions in a grassland mixture under low nitrogen fertilization and two cutting frequencies. II. Nutritional quality. Grass and Forage Science 72: 333-342.

Finn, J.A., Kirwan, L., Connolly, J., Sebastià, M.T., Helgadottir, A., Baadshaug, O.H., Bélanger, G., Black, A.D., Brophy, C., Collins, R.P., Cop, J., Dalmannsdottir, S., Delgado, I., Elgersma, A., Fothergill, M., Franklow-Lindberg, B.E., Ghesquiere, A., Golinska, B., Golinski, P., Grieu, P., Gustavsson, A.M., Hoglind, M., Huguenin-Elie, O., Jorrgensen, M., Kadziuliene, Z., Kurki, P., Llubra, R., Lunnan, T., Porqueddu, C., Suter, M., Thumm, U. and 
Lüscher, A. 2013. Ecosystem function enhanced by combining four functional types of plant species in intensively managed grassland mixtures: a 3-year continental-scale field experiment. Journal of Applied Ecology 50: 365-375.

Frame, J. and Newbould, P. 1986. Agronomy of white clover. Advances in Agronomy 40: 88.

Frame, J. and Laidlaw, A.S. 2011. "Improved Grassland Management". Crowood Press, Marlborough, UK.

Keating, T. and O'Kiely, P. 2000a. Comparison of old permanent grassland, Lolium perenne and Lolium multiflorum swards gown for silage: 2. Effects on conservation characteristics in laboratory silos. Irish Journal of Agricultural and Food Research 39: 25-33.

Keating, T. and O'Kiely, P. 2000b. Comparison of old permanent grassland, Lolium perenne and Lolium multiflorum swards grown for silage: 3 . Effects of varying fertiliser nitrogen application rate. Irish Journal of Agricultural and Food Research 39: 35-53.

King, C., McEniry, J. and O'Kiely, P. 2012a. A note on the fermentation characteristics of red clover silage in response to advancing stage of maturity in the primary growth. Irish Journal of Agricultural and Food Research 51: 79-84.

King, C., McEniry, J., Richardson, M. and O'Kiely, P. 2012b. Yield and chemical composition of five common grassland species in response to nitrogen fertiliser. Acta Agriculturae Scandinavia 62: 644-658.

King, C., McEniry, J., Richardson, M. and O'Kiely, P. 2013. Silage fermentation characteristics of grass species grown under two nitrogen fertilizer inputs and harvested at advancing maturity in the spring growth. Grassland Science 59: 30-43.

Lorenzo, B.F. and O'Kiely, P. 2008. Alternatives to formic acid as a grass silage additive under two contrasting ensilability conditions. Irish Journal of Agricultural and Food Research 47: 135-149.

Lüscher, A., Mueller-Harvey, I., Soussana, J.F., Rees, R.M. and Peyraud, J.L. 2014. Potential of legume-based grassland-livestock systems in Europe: a review. Grass and Forage Science 69: 206-228.

Moloney, T., Sheridan, H., Grant, J., O'Riordan, E.G. and O'Kiely, P. 2020a. Herbage nutritive value of binary- and multi-species swards relative to single-species swards in intensive silage systems. Irish Journal of Agricultural and Food Research 59: 167-184.

Moloney, T., Sheridan, H., Grant, J., O'Riordan, E.G. and O'Kiely, P. 2020b. Yield of binary- and multi-species swards relative to single-species swards in intensive silage systems. Irish Journal of Agricultural and Food Research 59: 12-26.

Moran, J.P., O'Kiely, P., Wilson, R.K. and Crombie-Quilty, M.B. 1990. Enumeration of lactic acid bacteria on grass and the effects of added bacteria on silage fermentation. Irish Grassland \& Animal Production Association Journal 24: 46-55.

Moselhy, M.A., Borba, J.P. and Borba, A.E.S. 2015. Improving the nutritive value, in vitro digestibility and aerobic stability of
Hedychium gardnerianum silage through application of additives at ensiling time. Animal Feed Science and Technology 206: 8-18.

Muck, R.E., O'Kiely, P. and Wilson, R.K. 1991. Buffering capacities in permanent pasture grasses. Irish Journal of Agricultural Research 30: 129-141.

Navarro-Villa, A., O’Brien, M., López, S., Boland, T. and O'Kiely, P. 2011. In vitro rumen methane output of red clover and perennial ryegrass assayed using the gas production technique (GPT). Animal Feed Science and Technology 168: 152-164.

Nyfeler, D., Huguenin-Elie, O., Suter, M., Frossard, E., Connolly, J. and Lüscher, A. 2009. Strong mixture effects among four species in fertilized agricultural grassland led to persistent and consistent transgressive overyielding. Journal of Applied Ecology 46: 683-691.

O'Kiely, P. and Wilson, R.K. 1991. Comparison of three silo types used to study in-silo processes. Irish Journal of Agricultural Research 30: 53-60.

Pahlow, G., Muck, R.E., Driehuis, F., Oude Elferink, S.J. and Spoelstra, S.F. 2003. 2 Microbiology of ensiling. Silage Science and Technology 42: 31.

Phelan, P., Moloney, A.P., McGeough, E.J., Humphreys, J., Bertilsson, J., O'Riordan, E.G. and O'Kiely, P. 2015. Forage legumes for grazing and conserving in ruminant production systems. Critical Reviews in Plant Sciences 34: 281-326.

Pirhofer-Walzl, K., Søegaard, K., Høgh-Jensen, H., Eriksen, J., Sanderson, M.A. and Rasmussen, J. 2011. Forage herbs improve mineral composition of grassland herbage. Grass and Forage Science 66: 415-423.

Playne, M.J. and McDonald, P. 1966. The buffering constituents of herbage and of silage. Journal of the Science of Food and Agriculture 17: 264-268.

Sanderson, M.A. 2010. Nutritive value and herbage accumulation rates of pastures sown to grass, legume, and chicory mixtures. Agronomy Journal 102: 728-733.

Sanderson, M.A., Labreveux, M., Hall, M.H. and Elwinger, G.F. 2003. Nutritive value of chicory and English plantain forage. Crop Science 43: 1797-1804.

SAS. 2013. "Version 9.4". SAS Institute Inc., Cary, NC, USA.

Tilley, J.M.A. and Terry, R.A. 1963. A two-stage technique for the in vitro digestion of forage crops. Journal of the British Grassland Society 18: 104-111.

Weissbach, F. and Honig, H. 1996. Über die Vorhersage und Steuerung des Gärungsverlaufs bei der Silierung von Grünfutter aus extensivem Anbau. Landbauforschung Völkenrode 46: 10-17.

Wilson, R.K. and Collins, D.P. 1980. Chemical composition of silages made from different grass genera. Irish Journal of Agricultural Research 19: 75-84. 